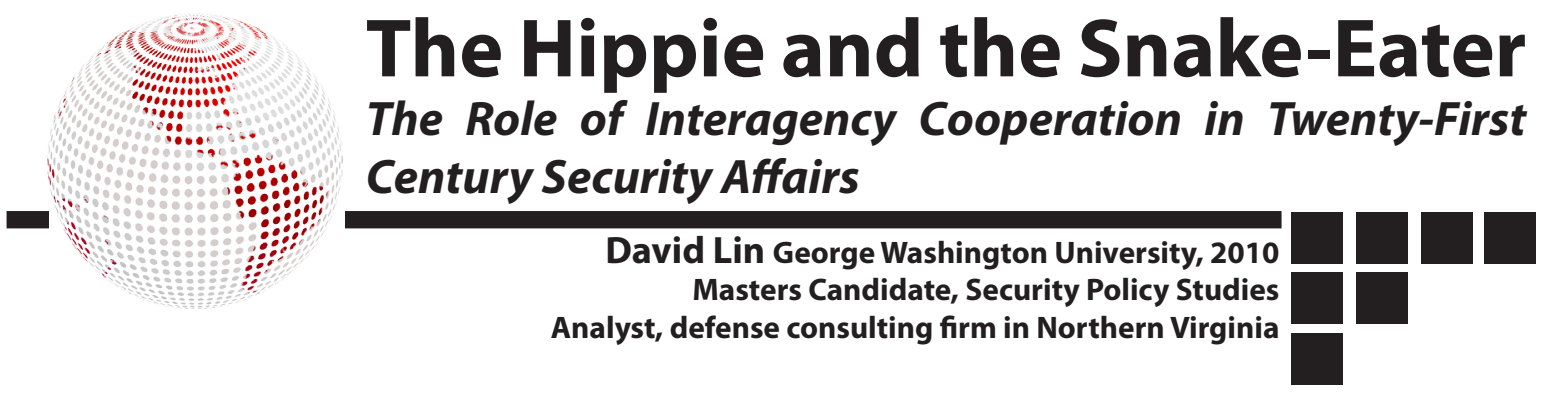

Anearly-2008Foreign Policy index found that $88 \%$ of active and retired American servicemen and women agree that the war in Iraq has stretched the United States military dangerously thin. ${ }^{\prime}$ Another $60 \%$ think that the US military today is weaker than it was fiveyearsago.74\% of those surveyed hold low regards for the civilian leadership expressing that civilian policymakers set unreasonable goals for the US military to accomplish. With current military operations in Iraq and Afghanistan serving as backdrops, these inflections serve as the basis of a much-needed conversation on the evolving roles and responsibilities of civilian and military agencies in the post-conflict environment.

The immediate solutions to the military's frustrations have been logical if not only reactionary or temporary stopgaps. If the military is stretched too thin, then expand it. Over the next five years there will be substantial increases in the Army and Marine Corps by as much as over 90,000 troops. ${ }^{2}$ If the military is weakening, then strengthen it. The President's 2008 defense budget pushes defense spending to levels not seen since the Reagan Administration, bringing with it a slew of new military hardware meant to keep the US military on the cutting edge of technology and flexible in the face of emerging threats. If the military is lacking comprehensive training and doctrine to combat insurgencies, then revise doctrine. In December 2007, the US Army and Marine Corps revamped their Counterinsurgency Field Manual, the first time in over two decades either service had published a field manual devoted to counterinsurgency. ${ }^{3}$

The next President of the United States will face a dynamic range of transnational threats that will likely make us rethink the way modern wars are fought. From terrorism and counterinsurgency to combating the spread of weapons of mass destruction, from illicit trafficking of drugs, people, and guns back to traditional conventional warfare with rising superpowers such as China and Russia, the United States must maintain a variety of diplomatic and military responses at its disposal. As emerging threats in the twenty-first century appear to be rooted at the nexus of security and development, a single-sided military solution cannot fully resolve a multi-dimensional problem. There is a need to develop a more comprehensive civil-military approach to combating terrorism, insurgency, and asymmetric warfare, something that has not fully materialized on the strategic or on the operational level. In order to do this, there is a need to tear down the stereotypes and reintroduce the hippie (statesmen) to the snake-eater (soldier).

\section{Civilian, Soldier}

In November 2007, a United States Cabinet-level official presented a compelling case for an increase in State Department funding during a speech in Kansas. The official pointed outhow $\$ 700$ billion circulates through the Pentagon whereas a meager $\$ 35$ billion is spent on the State Department - the same amount the Pentagon spends on healthcare alone. The official went on to highlight how only 6,600 Foreign Service officers serve in 265 posts around the world - less than the number of military personnel serving on just one US Navy aircraft carrier strike group. Furthermore, the official pointed out that the US Agency for International Development has seen a debilitating drop in number of staff, from 15,000 during Vietnam, to about 3,000 in the 1990s and now is faced with a workforce of which $30 \%$ are eligible to retire. 
Secretary of State Condoleezza Rice, however was not the one to deliver these staggering numbers. Instead, the uncanny proponent of stronger State Department funding was none other than Robert Gates, the US Secretary of Defense. ${ }^{4}$

Secretary Gates'speech reveals notonly the dire need for ramped up State Department involvement in stability operations, but symbolizes perhaps an long-needed reach across the cultural divide between the State Department and the Pentagon, bringing a connection between traditional adversaries in the political-military realm. Secretary Gates would go on to say, "I am here to make the case for strengthening our capacity to use soft power and for better integrating it with hard power" drawing a clear recognition that the military alone cannot stabilize a country on the verge of collapse, and that there needs to be a balance between soft power (diplomacy) and hard power (military force) in order to form an effective stabilization effort in a post-war environment. Indeed, this is one of the major lessons learned in Iraq and Afghanistan. As the United States continues its efforts to stabilize Iraq and Afghanistan and looks toward developing better approaches to trouble spots around the world, it is now faced with a dilemma within its military and civilian ranks - how to balance civilian expertise and military brawn in stability operations.

In October 2007, the United States Department of State announced that it would direct Foreign Service Officers (FSO) to deploy to Iraq as a result of fifty vacant posts in the US Embassy in Baghdad. ${ }^{5}$ If volunteers failed to fill the gap, the Department would fill the posts through directed or mandatory assignments. The American Foreign Service Association, representing 26,000 retired and active State Department personnel serving worldwide responded in protest: "We believe...that directing unarmed civilians who are untrained for combat into a war zones should be done on a voluntary basis." assignments to Iraq was something that had not been implemented by the Department since the Vietnam War and generated heated debate in a town hall-style forum organized by senior State Department officials provoking one officer to comment that being deployed to Iraq was "as good as a death sentence."

Across the Potomac at the Pentagon, a different story was taking shape. Leaders of the military services were struggling to justify massive expenditures on combat systems that appeared to remain focused on conventional warfare. Large defense projects ranging from the F-22 Raptor to the Zumawalt-class destroyer were facing criticism and resistance due to their decreasing relevance in the face of land-based unconventional adversaries. The military balance was tilting heavily in favor of unconventional and more flexible land-based military technologies with a focus on asymmetric warfare. As violence in Iraq continued to increase and while political pressure grew stronger for a change of course, the Bush Administration decided to deploy an additional 20,000 troops to Iraq as apart of a troop"surge"to bolster security and combat the insurgency. As the intensity of the insurgency in Iraq continued to fluctuate, soldiers on the ground found themselves conducting an array of tasks beyond traditional war fighting. War fighting became less and less like the war they had trained for - soldiers were patrolling the streets, conducting house-to-house raids, mediating local disputes, and training Iraqi police and soldiers. Soldiers undertook development and infrastructure projects, paving roads, restoring basic utilities, and building schools. Troops quickly discovered that they were doing much more than fighting an insurgency; they were in fact, nation building.

Where civilian capabilities dwindled, the Defense Department filled the gap by default, taking on many of the reconstruction and governance duties. By virtue of being a deployment and recruitment-based organization centered on training and force projection, the Pentagon mobilized to 
compensate for inadequate civilian capacity or capabilities. However, the deficiency in civilian agencies' ability to deploy the needed expertise and personnel into the field of operations has also adversely affected the military's mission. It has expanded the military's mission substantially as soldiers have been forced to take on tasks such as economic reconstruction, judicial reform, and political mediation - things that have been traditionally outside the scope of the military's realm of war-fighting. ' The civilian gap has resulted in an extension the duration of the military's mission, compounding problems of readiness, force allocation, force rotation, and ultimately, combat readiness for future conflicts. ${ }^{8}$ In Secretary Gates' words: "Our brave men and women in uniform have stepped up to the task, with field artillerymen and tankers building schools and mentoring city councils - usually in a language they don't speak. They have done an admirable job...but it is no replacement for the real thing - civilian involvement and expertise." ${ }^{\prime 9}$

\section{Crisis Spurs Innovation}

The call for federal agencies to act has not entirely fallen on deaf ears. In early 2005, a new standing Task Force for Financial Reconstruction and Stabilization was created at the Department of Treasury to lend expertise in economic development to the war effort. ${ }^{10}$ As apart the roll out of the Provincial Reconstruction Teams (PRTs) in Afghanistan in 2005, the Department of Agriculture deployed a mix of veterinarians, soil specialists, food safety experts, and an array of other specialists as apart of the PRTs to focus on agricultural development projects. ${ }^{11}$

From the Defense Department's Quadrennial Defense Review (QDR) in 2006, two civilian-centric national security concepts were proposed: the Civilian Linguist Reserve Corps and a National Security Officer Corps. The Civilian Linguist Reserve Corps, a network of volunteer linguistic experts that would respond at a time of national or international crisis, recognizes the importance of microlevel strategic communication - ensuring that the true intentions and goals of the US government in the field is not misinterpreted in any way on the tactical level. The NLSC is also just one component of President Bush's National Security Language Initiative (NSLI), a nationwide effort to expand language education from primary education through professional development. Both NLSC and NSLI recognize the importance of language skills in US security interests and how "deficits in foreign language learning and teaching negatively affect our national security, diplomacy, law enforcement, intelligence communities and cultural understanding."12

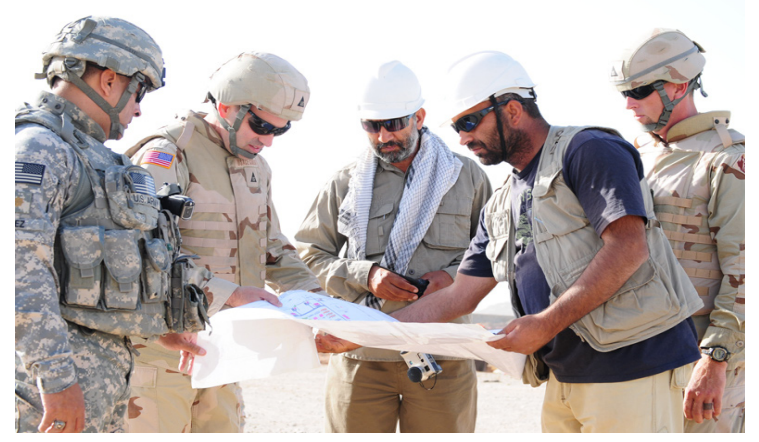

Another proposal set forth by the QDR that has yet to gain traction is the National Security Officer Corps (NSOC), a self prescribed "interagencycadreofseniormilitaryand civilian professionals able to effectively integrate and orchestrate the contribution of individual government agencies".13 Interestingly, Foreign Policy's survey among members of the US armed services (cited earlier in this paper) assesses that few military personnel see the need of such a contingent. In fact, when given the choice to pick two things "[The US military] must do to prepare for the threats and challenges of the $21^{\text {st }}$ century," developing a "cadre of operational, deployable civilian experts" ranked as the least important with increasing the size of the ground forces as the most important. ${ }^{14}$

In addition, the NSOC sounds heavily reminiscent of the US National Security 
Council, which was established to, "[serve] as the President's principal arm for coordinating [national security and foreign policies] among various government agencies." 15 In fact, one of the central recommendations to a report sponsored by the Council on Foreign Relations is to have stability and reconstruction policy indoctrinated into the NSC in order to formally coordinate the interagency process. ${ }^{16}$

On the State Department side of things however, the idea of a "cadre of operational, deployable civilians" is gaining momentum. In August 2004, the State Department created the Office of the Coordinator for Reconstruction and Stabilization (CRS), one of the first major institutional changes to come from post-conflict Iraq and Afghanistan. Since its creation, CRS has been tasked with being the lead civilian office in coordinating stabilization and reconstruction operations and has made proposals to answer the call for a more deployable civilian capability to warinflicted areas, one of the proposals being a three-tiered Civilian Response Corps. ${ }^{17}$

The Civilian Response Corps (CRC) would ultimately be composed of a small active response corps consisting of 250 civilian personnel being pulled from an array of federal agencies with the ability to deploy within 72 hours of a military deployment. The initial deployment could be as long as one-year. The standby and reserve corps, the second and third tier of the total force that would consist of upwards of 4,000 civilians combined, would be deployable within weeks and would tap into the resources of the private sector as well as other branches of the US government.

The CRC concept seeks to fill the gap in civilian presence and expertise in crisis areas in post-conflict stability and development activities. Debatably, the lawlessness that immediately followed the fall of the Saddam regime in Iraq could have been avoided if a robust contingent of civilian governance and rule of law experts were present to help the society transition and stabilize from war to peace. On March 5 2008, the US House of
Representatives passed the Reconstruction and Stabilization Civilian Management Act, which was the first step in moving towards the real establishment of such a force.

\section{Interagency on the Operational Level}

The Provincial Reconstruction Team (PRT) provoked much controversy when it was first fielded in June 2005, but proves itself as a useful and weather-tested civil-military interagency model on the operational level. While the structure and organization of PRTs in Iraq and Afghanistan have varied, their core mission has remained the same, centered on governance, reconstruction, and security mission areas.

The PRT's governance mission involves improving the ability for provincial and even municipal governments to restore the rule of law and return to providing basic services. One study drew a direct correlation between basic services and violence and its conclusion was quite simple: areas that lacked basic utilities such as water, electricity, or sewage treatment, gave rise to higher levels of violence. ${ }^{18}$ The other part of the governance mission concerns establishing the rule of law. Indeed soon after the fall of the Saddam regime, reports of theft and robbery consumed the country-side, depriving Iraqi civilians the sense of basic human security. The lack of both basic services and basic legal frameworks of governance were attributed for fueling the insurgency after the fall of Baghdad.

PRTs' second mission sought to undertake reconstruction projects such as building local schools and clinics to fuel social and economic development. Flexibility in micro-level funding, quickly became an issue, further complicated by interagency administrative hurdles and staffing issues.

The PRT's security mission evolved as the PRT's organizational structure evolved. In Afghanistan, PRTs are primarily military units, responsible for providing their own security and force protection. In Iraq, however, PRT security is the responsibility for either the 
Brigade Combat Team in which the PRT is embedded, or whatever military force's area of operation the PRT is operating in. What has remained consistent in the three PRT models, however, is that conducting military operations or military assistance is not apart of the PRT portfolio. Even while the PRT may be commanded by a military office, embedded with a military unit, or have armed military personnel as apart of it, the core PRT mission is development - political, economic, and physical development.

Three distinct types of PRTs have formed since the formal launch of the operations in 2005: the Afghanistan PRT, first-generation Iraq PRT, and the secondgeneration Iraq embedded PRT model. ${ }^{19}$ The Afghanistan PRT model was first deployed in June 2005 in close collaboration with the International Security Assistance Force (ISAF) in Afghanistan. A total of twenty-two PRTs were deployed, thirteen under US command, nine under ISAF control. These eighty-man teams were mostly composed of military personnel specializing in civil affairs and force protection and commanded by an Army Lieutenant Colonel. Only three civilians were apart of this model - one from the State Department, USAID, and US Department of Agriculture (USDA) respectively.

In November 2005, the US deployed ten PRTs to Iraq, this time under civilian control, led by Senior Foreign Service officers. The PRTs were similar in size as the Afghanistan PRTs, though they were comprised mostly of civilian rather than military personnel. The civilian component had representation from USAID, USDA, Department of Justice, and other cultural and linguistic specialists. The military component was slightly more refined, with a deputy leader, civil affairs soldiers, and a representative from the Army Corps of Engineers.

In January 2007, ten new PRTs were deployed in Iraq as apart of President Bush's "New Way Forward" strategy. Once again, a State Department official led the PRT, however, the State Department official would closely coordinate actions with a four-member core group that includes a representative from USAID, Army Civil Affairs, and a cultural advisor. Personnel from the National Guard or Army Reserve man the other civilian positions. The major new concept introduced in these PRTs is that they are "embedded" with a Brigade Combat Team, which also provides security for the PRT.

All in all, PRTs have proven to be perhaps one of the most innovative civilmilitary concepts to emerge in the wake of the wars in Afghanistan and Iraq. The PRT concept has called on typically domestic-focused federal agencies, once far removed from any war effort, to not only make foreign policy recommendations, but also deploy specialists on the ground into war zones. The PRT has also seen State Department Foreign Service officers deployed in virtual war zones, working alongside their military counterparts. PRTs have demonstrated at least the initial ability for the interagency process and civil-military integration to work relatively coherently on a tactical level. With the presence of civilian specialists, PRTs are able to undertake a fullspectrum approach to the conflict, helping to achieve stability through force and security fused with economic development and political reconciliation.

\section{Interagency on the Strategic Level}

The US Government must start developing a more unified and preventive strategy that will prepare it for emerging security challenges that utilize a multidimensional approach, finding a balance between conventional and unconventional military capability and also military and civilian capacity. While there still lacks a unified and integrated interagency doctrine, the concept of Security Cooperation, formally adopted within the Defense Department in 2001, can serve as a useful template in which to develop a more coherent and directed interagency framework. Joint Publication 3-0 defines 
security cooperation $\mathrm{as}^{20}$ :

All the Department of Defense (DoD) interactions with foreign defense establishments to build defense relationships that promote specific US security interests, developalliedandfriendlymilitarycapabilities for self-defense and multinational opeations, and provide US forces with peacetime and contingency across to a Host Nation. Joint actions such as nation assistance to include foreign internal defense, security assistance, and humanitarian and civic assistance; antiterrorism; DoD support to counterdrug operations; and arms control are applied to meet military engagement and security cooperation objectives. Security Cooperation is a key element of global and theater shaping operations and a pillar of WMD nonproliferation.

While based around the idea of peacetime military engagement, Security Cooperation is a useful strategic tool that can enhance civil-military cooperation as well as interagency coordination, making the national security organization as a whole better prepared for stability operations, such as those currently underway in Iraq and Afghanistan.

Joint Publication 3-0 brings about the range of activities that require not just interagency coordination, but international cooperation, which brings a whole other dimension to the concept unity of effort. From emergency preparedness to enforcing sanctions, from border security to counterinsurgency, Joint Publication 3-0 reviews just some of the military operations other than war that can benefit from strong international partnerships. The purpose of Security Cooperation is to not only build alliances, but also shape the broader politicalmilitary environment.

At the core of Security Cooperation is the idea of utilizing the Defense Department's diverse interactions with foreign defense establishments, such as combined exercises, combined training, combined education, military-to-military contacts, and information exchange. ${ }^{21}$ The importance of these diverse interactions with foreign establishments as prescribed by Security Cooperation can be easily related to those with domestic establishments as an effort to bolster the interagency process.

Activities such as field exercises, combined training, education, and meetings between civilian and military agencies would help overcome hurdles currently hindering the domestic interagency process, making the concept of Security Cooperation useful not only in shaping foreign alliances, but also domestic partnerships. Regularfield or tabletopexercises between Department of State Foreign Service Officers and Army officers would enable them to understand their respective professional cultures and decision-making processes. Encouraging Department of Agriculture and Department of Treasury personnel to take substantive classes in foreign affairs at State Department's Foreign Service Institute or the National Defense University would enable them to contextualize their work in the bigger global picture. Developing online regional or functional information sharing databases would facilitate a more open dialogue and exchange of ideas without even having to leave the office.

The newly created US Africa Command, or AFRICOM, launched in February 2007, attempts to incorporate this spirit of interagency security cooperation into its organizational structure. According to the website, this new ambitious combatant command will seek State Department and USAID personnel to be among its ranks, while encouraging partner nations, international organizations, and non-governmental organizations to work alongside US staff on shared objectives. ${ }^{22}$ Only time will tell if the US Africa Command can mobilize its soft-power approach in an effective and productive way.

Conclusion. The same way $9 / 11$ opened the United States' eyes to global terrorism and religious extremism, the wars in Iraq and Afghanistan have opened the United 
States eyes to the importance of developing a balanced approach to war and viewing conflict as a multi-dimensional process - one that cannot be resolved by force alone and one that cannot be dealt with by one agency or even necessarily one country alone.

The US Government is beginning to see a new kind of 'revolution in military affairs.' The US military and civilian agencies have made significant steps towards bridging the cultural divide but more must be done. While both State and Defense Departments have made commendable first steps in striking a balance in hard versus soft power, military versus civilian roles, there remains a need for strong leadership in interagency efforts, operationally and strategically. Provincial Reconstruction Teams serve as a useful interagency and civil-military model on the operational level, demonstrating the ability to address multiples sides of a conflict. Security Cooperation marks an important strategic development in defense strategy, and serves as a good point of reference by which to shape a more coherent interagency framework. As with all new initiatives, there will be challenges ahead.

Bolstering interagency efforts will be a long and arduous process, one that will require persistent political will, clear vision, and likely span several Presidential Administrations. The effort will call for innovation, institutional soul-searching, and a frame of mind where hard power and soft power are not mutually exclusive. The military force should remain rooted in effectively conducting war-fighting operations in pursuit of military objectives. The diplomatic corps should likewise continue concentrating on representing and defending US interests abroad. However, both sides of the house - civilian and military - should be prepared, able, and willing to cooperate as a unified force in countering the emerging threats of the twenty-first century problems. For in the final analysis, multi-dimensional problems require equally multi-dimensional solutions. It will be imperative for the next Administration to recognize that.

\section{Endnotes}

"U.S. Military Index". Foreign Policy Magazine March/April 2008: 70-80.

2 Tyson, Ann Scott. "Bush's Defense Budget Biggest Since Reagan Era." The Washington Post 6 February 2007. A06. 10 March 2008 <http://www. washingtonpost.com/wp-dyn/content/article/2007/02/05/AR2007020501552.html/>.

${ }^{3}$ Gordon, Michelle. "Army, Marine Corps unveil counterinsurgency field manual" US Army News 15 December 2006.18 October 2008. <http://www. army.mil/-news/2006/12/15/1005-army-marine-corps-unveil-counterinsurgency-field-manual/>

${ }^{4}$ Gates, Robert. "Landon Lecture at Kansas State University" Manhattan, Kansas (26 November 2007). Retrieved on 10 March 2008. <http://www. defenselink.mil/speeches/speech.aspx?speechid=1199>.

${ }^{5}$ DeYoung, Karen. "State Dept. To Order Diplomats To Iraq." The Washington Post 27 October 2007. A01. 10 March 2008 <http://www.washingtonpost. ${ }^{6} \mathrm{Ibid}$ com/wp-dyn/content/article/2007/10/26/AR2007102602417.html>.

${ }^{7}$ Murdock, Clark and Michele A. Flournoy. "Beyond Goldwater-Nichols: US Government and Defense Reform for a New Strategic Era." Washington, DC: Center for Strategic International Studies, July 2005.

${ }^{8}$ Nash, William L. "In the Wake of War: Improving U.S. Post-Conflict Capabilities." Washington, DC: Council on Foreign Relations, July 2005.

${ }^{9}$ Gates, Robert. "Landon Lecture at Kansas State University" Manhattan, Kansas (26 November 2007). Retrieved on 10 March 2008. <http://www. defenselink.mil/speeches/speech.aspx?speechid=1199>.

${ }^{10}$ Nash, William L. "In the Wake of War: Improving U.S. Post-Conflict Capabilities." Washington, DC: Council on Foreign Relations, July 2005.

${ }^{11}$ Perito, Robert. "The US Experience with Provincial Reconstruction Teams in Afghanistan: Lessons Identified." Washington, DC: US Institute of Peace, October 2005

${ }^{12}$ Powell, Dina and Barry Lowenkron. “Briefing on National Security Language Initiative." US Department of State.Washington, DC: 5 January 2006.

13 "Quadrennial Defense Review Report." US Department of Defense. 6 February 2006: 78-79.

14 "U.S. Military Index". Foreign Policy Magazine March/April 2008: 70-80.

15 "The White House." National Security Council. 9 March 2008. The White House. <http://www.whitehouse.gov/nsc/>

${ }^{16}$ Nash, William L. "In the Wake of War: Improving U.S. Post-Conflict Capabilities." Washington, DC: Council on Foreign Relations, July $2005: 11$.

${ }^{17}$ Wright, Robin. "Civilian Response Corps Gains Ground" The Washington Post 15 February 2008. A19. 11 March 2008. <http://www.washingtonpost. com/wp-dyn/content/article/2008/02/14/AR2008021403433.html?nav=rss_politics>

${ }^{18}$ Chiarelli, Peter W. and Patrick Michaelis. "Winning the Peace: the Requirement for Full-Spectrum Operations." Military Review July/August 2005: 417.Ibid.

${ }^{19}$ Perito, Robert. "The US Experience with Provincial Reconstruction Teams in Iraq and Afghanistan." Washington, DC: Testimony before the House Armed Services Subcommittee on Oversight and Investigations. 18 October 2007.

20 Joint Publication 3-0. US Department of Defense. February 2008.

${ }^{21}$ Reighard, Robert. "Security Cooperation Integrating Strategies to Secure National Goals." Carlisle, PA: US Army War College Strategy Research Project, 15 March 2006.

22 "About AFRICOM," US Africa Command. 19 October 2008. <http://www.africom.mil/AboutAFRICOM.asp>

Photo Courtesy thanks to U.S. Military 